\title{
The Problem Of Special Needs Student In The Learning Process At Lambung Mangkurat University
}

\author{
Eviani Damastuti, Dewi Ekasari Kusumastuti, Mirnawati, Rohmah Ageng Mursita \\ Department of Special Education \\ Lambung Mangkurat University \\ Banjarmasin, Indonesia \\ eviani.damastuti.plb@ulm.ac.id
}

\begin{abstract}
Inclusive education is a system of education service that provides opportunities for children with special needs to be able to study in regular schools. The development of inclusive education has grown to the level of higher education. Lambung Mangkurat Univeristy is the university that accepts students with special needs. However, there are still many problems faced by special needs students in the learning process. The purpose of this research is to know the problem of special needs students in the learning process at Lambung Mangkurat University. The approach used in this research was qualitative approach with case study research type. The data sources in this research were volunteers, lecturer, special needs students, and regular students while secondary data sources were documentation, photos, activity note and letters. Techniques of collecting data in this research were interview, observation, and documentation. Data analysis techniques used was interactive analysis. The results showed that there was no modification for teaching materials of special needs student, coordination between volunteers and lecturers was still lack, and volunteers were ready to help special needs students in the learning process. Regular students have been willing to accept special needs student and to be invited to work together to help special needs student. Many lecturers do not understand the condition of special needs student that special needs students have difficulty in attending lectures and understanding the materials, There was no assistive technology that can help special needs student during the lecture process, Evaluation of learning outcomes for special needs student has not been modified.
\end{abstract}

Keywords-problem; special needs student; the learning process.

\section{INTRODUCTION}

Education has a very important role in the development of a Nation and State that the quality of human resources can be improved. Therefore, the government gives equal rights for every citizen to get education. Equitable and proper education without discrimination is ideal for society. In order to realize the desire of the community to have education without discrimination, the government issued Minister of Education Regulation No. 70 of 2009 concerning Inclusive Education. Inclusive education is a system of education service that requires children with special needs to study in the nearest schools in ordinary classes with friends of their age [1]. By having inclusive education, children with special needs are given the opportunity to study in regular schools. Hence, in carrying out inclusive schools, all children are accepted regardless of the child's background such as race, ethnicity, religion, and culture even those who include children with special needs (blind, deaf, mentally disabled, autistic, gifted, etc.). Inclusive schools provide education programs that are tailored to the abilities and needs of each child with support and collaboration between teachers, parents and the surrounding community.

Inclusive education does not only apply to primary and secondary schools, but the development of inclusive education has reached the level of higher education. This was welcomed by the government with the issuance of Pemenristekdikti No. 46 of 2017 concerning Special Education and Special Services in Universities. This confirms that Higher Education provides opportunities for children with special needs to have the potential and ability to receive higher education. Following up on Permenristekdikti No. 46 of 2017, Lambung Mangkurat University started accepting students with special needs in the 2017/188 school year.

Students with Special Needs at Lambung Mangkurat University were initially accepted through an independent batch Lambung Mangkurat University. There were 9 (nine) students with Special Needs were accepted in Lambung Mangkurat University consisted of 8 students accepted in the Faculty of Teacher Training and Education, and 1 student at the Faculty of Economics and Business. Students with special needs who have been accepted at the University of Lambung Mangkurat must be given facilities in learning and assessment according to the needs of each student with special needs. References state that inclusive class arrangements must be strengthened and supported by a cadre of specially trained personnel and other support that suits the individual needs of children. The focus of this research is students with special needs in Faculty of Teacher Training and Education of Lambung Mangkurat University especially in the Special Education Study Program considering the highest number of students with special needs.

Observations showed that there were many problems faced by students with special needs, especially when attending the 
lecture. Therefore, more complete and in-depth information were needed regarding the problems faced by students with special needs so that the right solutions can be given. Thus, the the purpose of this study was to find out the problems of special needs student in the learning process at Lambung Mangkurat University.

\section{METHOD}

The approach used in this study was a qualitative approach using case study. The selection of a qualitative approach was considered in accordance with the problems studied which intended to find out the objective conditions in a natural setting. It was expected that with this qualitative approach researchers could explore the problems of students with special needs in the learning process deeply and thoroughly using interview or observation techniques that involved researchers as core instruments in the field. The sources of the data in this study were volunteers (accompanying Students with Special Needs Students), lecturers, special needs students, regular students while the secondary data sources were documentation and observation notes. Data collection techniques in this study were interviews, observation, and documentation. This research data analysis was carried out with an interactive model. Data analysis is shown in the following figure:

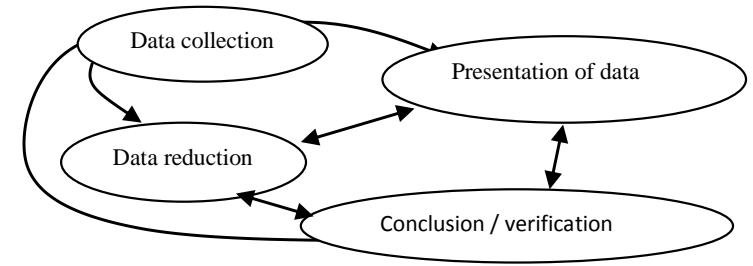

Fig. 1. Components of Data Analysis (Interactive Model) [3]

\section{RESULT AND DISCUSSION}

This study aims to find out the problems of special needs student in the learning process at Lambung Mangkurat University. The results showed that the problems faced by students with disabilities began with the lack of understanding of the lecturers about the conditions and learning needs of students with special needs especially the lecturers who are not from the Special Education program. The problems arose from the lack of understanding of the lecturer on the learning needs of students with special needs which gave an impact in the absence of unmodified teaching materials, while in fact, there were 8 (eight) students with special needs in the classroom. Students with special needs were 5 students with hearing impairment, 1 student with visual impairment, 1 student with physically impairment and 1 student with autistic disorder. Students with special needs were put together in one class with a total of 30 regular students. This caused the teaching materials made by the lecturer were only focused on regular students. Modification of teaching materials for students with special needs can be done by lecturers with the help of volunteers. Another solution is that the task of modifying teaching materials can be done by providing teaching materials to volunteers, and they will be in charge of modifying. Volunteers are regular students who volunteer to assist students with special needs if they have difficulties in getting information and in lectures. However, the observation results showed that the lecturer did not have coordination with volunteers before the learning process, even if there was coordination, it was still very little. Collaboration in inclusive classes is needed so that learning process is more effective. This is in line with the results of reference [4] about study of teacher behavior in inclusive school settings which was exemplified by positively effective collaboration. Teachers and professionals collaborate to do this by sharing professional responsibilities. This category includes a description of the teacher in making a commitment: to jointly educate students, to jointly prepare and present information for students at meetings, and to jointly uphold responsibility for each student.

During the learning process, the lecturer was not alone in teaching students with special needs, but the lecturer was assisted by volunteers. However, the number of volunteers is still limited and they are mostly from 5th semester and 7th semester students. Volunteers from the 5th semester who are committed to assist students with special needs are mostly from the same class so that when both of them have classes in the same time, there are no volunteers who help students with special needs. In addition, there was an obligation to take field experience practices at school that they finally could not replace volunteers from semester 5. If volunteers could not assist students with special needs during the learning process, students with special needs were assisted by regular students. Regular students have welcomed the students with special needs, but at the beginning of the class, regular students who wanted to be invited to work together to help students with special needs were still limited. The awareness of regular students in assisting and helping students with special needs was growing more and more. This is shown by the availability of involving students with special needs in their groups. Reference [5] states that in an inclusive school setting, learning emphasizes the cultivation of an attitude of sympathy, respect, appreciation and empathy for different socio-cultural backgrounds.

Problems in the learning process were not only faced by volunteers and regular students. However, students with special needs also experienced problems during the learning process that arose from their own special needs. Problems faced by students with special needs could be related to their disability and there were problems that were not related their disability. Problems related to disability such as deaf students had problems with the lack of vocabulary they had so that deaf students had difficulty in understanding the material during the learning process, especially words that were abstract in nature such as "flower" which also means the "development". In addition, the preparation of word structures of students with hearing impairment was often flipped back and forth. This would also greatly affect the understanding of students with hearing impairment. Reference [6] concluded that language deficits do not hinder the deaf from thinking normally, because if he controls the influence of language on a large number of cognitive tasks, it was found that the performance of deaf subjects was very little different from their non-deaf peers. If 
the difference arises, he argues that it is caused by a lack of experience or unknown tasks or concepts being tested, not because of cognitive deficits in general due to hearing loss and / or due to language deficits. Other problems that occurred during the learning process that were not related to disability were students with special needs felt they could do everything by themselves without the help of volunteers. In fact, they had difficulty in following the learning process and understanding teaching materials. In addition, the attitude of students with special needs was not cooperative when assisted by volunteers. Students with special needs did not want to be arranged in a seating position; he did not want to sit on the front side even though it made them easier to see the lip movements of the lecturer and more clearly looking at the LCD screen.

Learning services during lectures for students with special needs were different from regular students. This is because the conditions, obstacles and learning needs of students with special needs are also different. There were five students with special needs found in the special education program who mostly experienced hearing impairment (deaf). Students with special needs who experienced hearing impairments can learn and access information through their visuals. Thus, students with hearing impairments require media in a visual form, whereas during the learning process and most of the learning methods used by lecturers was lecturing. The impact of using the information lecture method in learning process was that it was not accessible to students with hearing impairment. Different from students with hearing impairment, student with physically and student with autistic disorder had no difficulty in learning in the form of audios. Yet, students with hearing impairment during lectures need technology that can help them understand teaching materials/lectures, which is called assistive technology. In accordance with the opinion of Reference [7], the term assistive technologies refer to the equipment, devices and apparatus, and the services, systems, processes and adaptations made to the environment that support their functions, used by persons with special education needs. Assistive technology is tailored to the needs of people with hearing impairment, for example technology that can convert sound to writing, so that lecturers who mostly teach using the lecture method can be automatically translated by writing that can be read by the student with hearing impairment. Students with visual impairment have problems with their vision so that in the lecture process, blind students need special services; they can learn to use a laptop installed by the JAWS program that can read the screen reader. However, the problem is that the lecturer did not provide soft file material for students with visual impairment before or during the lecture. Consequently, they learned by listening to the explanation from the lecturer during the lecture. Students who do not have problems with their sense of hearing and vision did not face many problems during the learning process. Likewise, autistic students had only few problems encountered during the learning process. In a study conducted by Reference [8], the factors that influence the success of the study of students with disabilities mostly come from external factors such as assistants who are less helpful, difficulties access to campus, and difficulties accessing information. In addition, the constraints of external factors are also strongly influenced by internal factors. This is related to the readiness of students with special needs, while on campus, they need competence in the academic field. Most students with special needs accepted at Lambung Mangkurat University especially Special Education program came from Special Schools (SLB) before, which most of the subject matters at special schools emphasize more on skills. This is in line with the research conducted by Reference [9], which shows that schools must prepare for the needs of post high school students who will work and who will continue to college. Students with special needs who have desires to continue their education to college are ruled out. Hence, schools need to conduct counseling and try out for students with special needs who continue their education to universities.

Evaluation of learning outcomes was carried out by the lecturer after the student finished the learning process. Evaluation of learning outcomes is used to determine the extent to which students understand the teaching materials given by the lecturer during the learning process. Evaluation of learning outcomes was shown as grades. The grades obtained by students are not just written test scores, but the score is also the cumulative score of students' activity during the learning process, score of individual assignments, group assignment scores and student exam scores. This evaluation of learning outcomes was not only valid for regular students but also was applied to students with special needs. The problem faced by students with special needs in evaluating learning outcomes was that students had difficulty in working on evaluation questions because there was no modification to the questions given to students with special needs.

\section{CONCLUSION}

Based on the results of the research and discussion that have been described, it can be concluded that the problems of students with special needs in the learning process at Lambung Mangkurat University are as follows:

- Lecturers did not understand the condition of students with special needs,

- Teaching materials for students with special needs have not been modified

- There were already volunteers who helped the condition of students with special needs in the learning process, but the numbers were still very limited

- There was a lack of coordination between volunteers and subject lecturers

- Regular students have recognized the conditions of students with special needs, and wanted to be invited to work together to help students with special needs,

- There were difficulties in attending lectures and understanding lecture materials

- There was no assistive technology that could help students with special needs during the learning process.

- Evaluation of learning outcomes for students with special needs has not been modified. 


\section{REFERENCES}

[1] D. P. Hallahan, J. M. Kauffman, and P. C. Pullen, Exceptional Children: An Introduction to Special Education, 11th ed. Boston, MA: Allyn \& Bacon, 2009.

[2] P. M. Ajuwon, D. Lechtenberger, N. G. Shirley, and F. E. Mullins, "General education pre-service teachers perceptions of including students with disabilities in their classrooms," International Journal of Special Education, vol. 27, no.3, pp. 100-107, Jan. 2012

[3] Sugiyono, Metodologi Penelitian Kuantitatif, Kualitatif, dan R\&D. Bandung: Alfabeta, 2011.

[4] B. H. Jones, and O. V. Cynthia, "Preparing special educators for collaboration in the classroom: pre-service teachers' beliefs and perspectives," International Journal of Special Education, vol. 29, no.1, pp. 76-86, 2013.
[5] Sukinah, "Manajemen strategik implementasi pendidikan inklusif. Jurnal Pendidikan Khusus," vol.7, no.2, pp. 40-51, Nov. 2010

[6] H. G. Furth, Thinking Without Language: Psychological Implications of Deafness. New York: Free Press, 1966.

[7] R. Erdem, "students with special educational needs and assistive technologies: a literature review," The Turkish Online Journal of Educational Technology, vol. 16, no. 1, pp. 128-146, Jan. 2017.

[8] S. Soeparman, "Faktor-faktor yang mempengaruhi keberhasilan studi mahasiswa penyandang disabilitas," Indonesian Journal of Disability Studies, vol. 1, no. 1, pp. 12-19, 2014

[9] U. F. Rizky, "Identifikasi kebutuhan siswa penyandang disabilitas pasca sekolah menengah atas," Indonesian Journal of Disability Studies, vol. 1, no.1, pp. 52-59, 2014. 